\section{Barbara Vujanović}

Muzeji Ivana Meštrovića, Atelijer Meštrović

DOI:

10.17685/Peristil.60.17

\section{Vesna Barbić (1925.-2017.)}

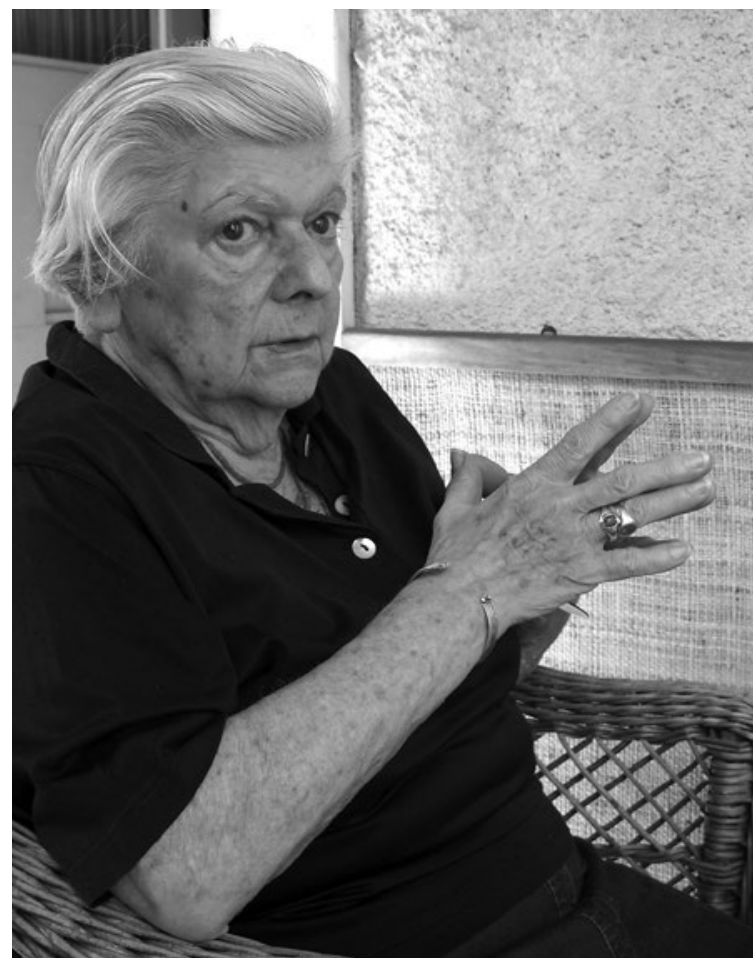

foto: Maro Grbić

U nedjelju, 12. veljače 2017., u 93. godini života preminula je Vesna Barbić (Zagreb, 1925.), povjesničarka umjetnosti iznimno plodne karijere, koja je posebno bila odredena proučavanjem opusa Ivana Meštrovića. Nadasve je zadužila zagrebački muzej Atelijer Meštrović, to jest Muzeje Ivana Meštrovića, instituciju u čije je temelje ugradila sav svoj profesionalni mar i interes za hrvatskog kipara.

Vesna Barbić diplomirala je 1951. godine povijest umjetnosti na zagrebačkom Filozofskom fakultetu. Prvo radno mjesto bilo joj je u arhivi Muzeja za umjetnost i obrt u Zagrebu, gdje je počela raditi još kao apsolventica, a u srpnju iste godine prešla je u Umjetničku galeriju Dubrovnik na mjesto kustosa i vršiteljice dužnosti ravnatelja. Godine 1955. postala je prva ravnateljica tek osnovane Galerije suvremene umjetnosti, današnjega zagrebačkog Muzeja suvremene umjetnosti. Ostatak radnog vijeka provela je u Atelijeru Meštrović, u kojem je bila zaposlena od 1960. godine pa sve do odlaska u mirovinu. Karijeru je završila u zvanju muzejske savjetnice.

Za svoj rad odlikovana je Priznanjem grada Zagreba, potom Nagradom Hrvatskoga muzejskog društva „Pavao Ritter Vitezović“, a za životno djelo i odličjem Reda Danice hrvatske s likom Marka Marulića.

Kao prva voditeljica i kustosica Atelijera Meštrović, najveći dio svoje bogate i ugledne karijere Vesna Barbić posvetila je izučavanju, zaštiti i promociji Meštrovićeve baštine. Transformiravši, u suradnji s Miroslavom Begovićem, Edom Kovačićem i Vojtjehom Delfinom, nekadašnji dom i radni prostor u muzejsku ustanovu, čiji stalni postav i danas fascinira svojom aktualnošću, formiravši arhivske i dokumentarne fondove, 
ona je utemeljila polazište za sva buduća istraživanja, kako u Hrvatskoj tako i u svijetu. Kao rijetko koji meštrovićijanac, Vesna Barbić jednako je suvereno obrađivala Meštrovićev kiparski, crtački i arhitektonski opus, kao i opuse njegovih suvremenika, poput Joze Kljakovića ili Grge Antunca. Njezina zavidna bibliografija posvećena Meštroviću nezaobilazna je referencija svim istraživačima. Osobnim kontaktom s kiparom i njegovom obitelji, ona je gradila spone između Meštrovića i njegove domovine, izmedu prošlosti, sadašnjosti i budućnosti.

Također, stručno je pomagala srodnim ustanovama: Gradski muzej u Drnišu i Spomen-galeriju „Ivan Meštrović“ u Vrpolju. Ipak, njezin rad u i na Atelijeru Meštrović zauvijek je obilježio sve djelatnike muzeja, one koji su radili s njom, te one koji su došli nakon nje. Od naših prvih dana, osim upijanja znanja o samom kiparu, upijali smo sjećanja na profesoricu Barbić, kako su je, s mnogo dragosti, zvali njezini kolege. Svi su isticali njezinu visoku profesionalnu etiku, na koju će uostalom zauvijek upućivati njezina djela. Ali ono po čemu je pamte njezini suradnici ponajprije su toplina, ljubaznost i iskren odnos prema svim djelatnicima. Primjerice, posebno je naglašavala ulogu tehničkog osoblja u muzejima o kojem nitko ne piše u publikacijama, o kojem nitko ne govori na otvaranjima izložbi, a važan su segment u svakodnevnom radu, osobito pri postavljanju izložbi.

Vesna Barbić bila je nesebična u dijeljenju svoga širokog i dubokog znanja, a s posebnim je zanimanjem pratila djelovanje muzeja koji je ustanovila. Radovali su je susreti sa starijim kolegama, i s mladima, koji su u njoj vidjeli svoj velik uzor i zalog muzejskog i istraživačkog rada. Baš kao što je Vesna Barbić posvetila svoju kreativnu energiju i predani rad Ivanu Meštroviću, tako je i naša zadaća da u svojem daljnjem djelovanju nastavljamo njezinu tradiciju, te da i budućim generacijama prenesemo sjećanje na ovu iznimnu i nadasve omiljenu kolegicu.

Tekst je objavljen u Kvartalu, XIV-1/2-2017. 